\title{
Dealing with Identity Loss and Well-being of Unemployed Young People
}

\author{
Anastasia Kitiashvili ${ }^{1}$, Nana Sumbadze ${ }^{2}$ \\ ${ }^{1}$ Associate Professor. \\ ${ }^{2}$ Professor Faculty of Psychology and Educational Science Tbilisi State University.
}

\begin{tabular}{ll}
\hline ARTICLE INFO & ABSTRACT \\
\cline { 2 - 2 } Keywords: & $\begin{array}{l}\text { The research aims to study the relationship between the status of } \\
\text { unemployment and social identity and well-being of young people. } \\
\text { youth }\end{array}$ \\
We conducted a quantitative survey with 110 unemployed young \\
people; In-depth interviews were conducted with 24 participants. \\
Findings show that the experience of unemployment is negative. It \\
causes financial problems, nurtures a feeling of dependence, negative \\
social identity; it is also linked to reduced opportunities for social and \\
cultural involvement. The attitude of society towards unemployed \\
differs according to what unemployment is attributed to. It is more \\
positive when it is assigned to the economic situation in the country \\
and hence to a lack of jobs, but is more harmful when it is attributed \\
to a lack of motivation or qualification of a person. To escape from \\
the negative social identity unemployed young people trying social \\
mobility. The long-term unemployed are more active than the short- \\
term unemployed. Unemployment effects well-being. Unemployed \\
youth is less than the general population satisfied with their life \\
although they have a similar level of self-esteem.
\end{tabular}

\section{Introduction}

Unemployment has an adverse effect on a person's life and well-being (Winkelmann and Winkelmann 1998; Young, 2012; Vinokur., \& Caplan 1987). Research reveals that job loss leads to decreased self-esteem (Jackson \& Warr, 1984; Sheeran \& McCarthy, 1990, 1992; Winefield\&Tiggeman, 1985, Waters \& Moore, 2001), increased depressive symptoms (Waters \& Moore, 2001, Catalano, 1991; Kessler, Turner \& House, 1988; 1989), anxiety (Catalano, 1991) and stress (Nordenmark, 1999a). Psychological problems caused by unemployment generate health concerns, which create challenges for societal life (Johada et al. 1933; Pal 2006). Unemployment positively correlates with social exclusion and isolation, called "social disqualification" (Paugam 2004), especially when unemployment is a long-term (Lorenzini, J

$\square$ Corresponding Author E-Mail Address: kitiashvili@yahoo.com 
\&Giugni, M. 2012). Thus unemployment can affect the well-being of the individual and shape her/his identity.

\subsection{Unemployment and well-being}

Well-being is a broad concept and is defined as a subjective evaluation of how one feels about and experiences their own life. Well-being is generally associated with positive beliefs and feelings and satisfying relationships, meaning and purpose in life (Friedli, 2009). Social psychological literature uses the following indicators of well-being: high self- esteem (Rosenberg, 1965), life satisfaction (Diener\&Diener, 1996), or lack of depression (Beck, Ward, Mendelson, Mock, \&Erbaugh, 1961).

Work is involved in satisfying several individuals and social needs (Maslow, 1954), such as income, stability, and security. Through work, we have contact with groups beyond the family, which is crucial for developing social skills and receiving social support (Jahoda, 1982). Work becomes a part of our self-concept and gives us a sense of who we are and where we belong.

Unemployment may present a challenge to the social fabric of an individual as friendships and hence social support in a considerable degree is determined by everyday social environment, a big part of which is employment site. (Bolton \&Oatley, 1987; Whyte, 1956). The job loss may cause a decrease in contact with friends, as friendships are harder to maintain when people are no longer employed in the same organization (Atkinson, Liem., \&Liem, 1986).

\subsection{Unemployment and Social Identity}

Next, to social needs, employment provides a big part of economic, stability, and security needs (Maslow, 1954). Job loss is a negative experience related to the loss of functional role and is a significant challenge to social identity (Friedland, D.S., \&Vinokur, A.D. 1998).

Erikson did not explicitly consider the effect of unemployment on identity formation during adolescence, but be pointed out the importance of "using the careers provided in the society" for a positive solution to an identity crisis, and maintained that "it is primarily the inability to settle on an occupational identity which disturbs young people" (Erikson, 1968, p. 92). Erikson (1959) considers professional identity as the most central domain of identity formation. With the emergence of a professional identity emerges accompanying self-regulation mechanisms creating values, beliefs, and commitments to work. Research shows that youth unemployment sets back healthy psychological development by making impossible the acquisition of professional identity (Gurney 1980).

Social identity (Tajfel, 1978; Tajfel\& Turner, 1979) and self-categorization theories (Turner, 1982, 1991; Turner, Hogg, Oakes, Reicher, \&Wetherell, 1987) can be used to analyze as for how people perceive their unemployment. 
Tajfel (1978, p. 63) defines social identity as "that part of an individual's self-concept that derives from (...) his knowledge of (...) membership of a social group (or groups) together with the value and emotional significance attached to that membership". Hence individuals develop their social identities from the groups to which they belong (Tajfel, 1978, 1982; Tajfel\& Turner, 1979).

People strive to achieve a definite sense of themselves and perceive the groups to which they belong as positively distinct from others on relevant dimensions (Tajfel, 1978). For individuals who belong to groups with high status, it is easy to do so, while the opposite is exact regarding those having low status (Schmitt \&Branscombe, 2002). Tajfel and Turner (1979, p. 19) postulated, "the lower is a group's status about relevant comparison groups the less is the contribution it can make to a positive social identity." One relevant criterion for the comparison with others is employment. Comparison according to these criteria is likely to hinder unemployed to derive a positive sense of self from their group membership. Thus they may face devaluation which will reflect negatively on their self-esteem (e.g., Branscombe, Schmitt, \& Harvey, 1999), resulting in a lower level of well-being (Schmitt, Branscombe, \& Postmes, 2003; Schmitt et al., 2014) and will contribute in creating a negative social identity.

\subsection{Strategies for escaping negative social identity}

Social Identity theory defines identity strategies that assist a person to avoid or diminish the negative consequences of existing, negative social identity. (Tajfel\& Turner, 1979). They include an individual based strategy -individual mobility, and two group-based approaches: social creativity and social competition.

Individual mobility strategy aims at pursuing an active personal identity. This is achieved by either behavioural means, leaving his/her own and joining another, a higher-status group (e.g., finding employment) or by a psychological mean, decreasing the level of the identification with own group (Tajfel\& Turner, 1986). People having lower levels of identification with own group are more likely to pursue individual strategies (Ellemers, Spears, \& Doosje, 1997; Kessler \&Mummendey, 2002; Mummendey, Kessler, Klink, \&Mielke, 1999), and hence in our example seek a job.

Attempt to leave one's group (of unemployed) and join the higher status group (of employed) is an effective strategy, although in case of repeated failure can easily result in the development of a withdrawal from the labor market.

People use group-based strategies when they believe that moving between groups is impossible and group boundaries seem to them impermeable. Social creativity is a way to see the own group in a better light (Tajfel\& Turner, 1979). Individuals remain in their own group but change how they compare to other groups. Social Identity Theory distinguishes three different ways in which people can improve their social standing through social creativity (Blanz et al., 1998; Tajfel\& Turner, 1979): First, individuals can define a new dimension in which the ingroup compares positively to the outgroup. Second, positive distinctiveness can be established by finding other outgroups with whom to correspond. Instead of comparing themselves to 
employed people, for example, unemployed people may compare themselves with homeless persons. A third strategy is to re-test the values or attributes of the ingroup positively.

Another strategy may be to restructure one's cognitions about the negative influence of unemployment. One form of cognitive reconstruction is that stigmatized people may compare with people who are similarly stigmatized (Crocker \& Major, 1989; Crocker et al., 1998). The second form of cognitive reconstruction is to selectively value those dimensions on which the one's group performs well and devalue those aspects on which the one's group performs poorly (Crocker \& Major, 1989). A third form is to attribute poor outcomes or performance to prejudice and discrimination (Crocker \& Major, 1989). For example, if an unemployed person does not get a job, he or she may believe that this was because the interviewer discriminated against her/him.

Individuals may use several strategies at the same time to cope with identity to maintain unemployment. It is indeed unlikely that only one approach may be useful across different situations (Miller \& Major, 2000).

\subsection{The context of Georgia}

Unemployment, notably of youth is acknowledged as the most troublesome problem in Georgia. Since 2010 the rate of unemployment decreased by $4.3 \%$ in the whole population and is at $12 \%$ now, and by $5.6 \%$ among youth (15-24 years old), but still stays high $30.8 \%$ ) (Geostat 2016). Youth unemployment is high across all levels of education, being highest among graduates of vocational education institutions (36\%).

Table1. Youth unemployment rate (15-24 years old) by educational level, 2013-2015

\begin{tabular}{|l|l|l|l|l|}
\hline$\#$ & & $\begin{array}{l}\mathbf{2 0 1 3} \\
\boldsymbol{\%}\end{array}$ & $\begin{array}{l}\mathbf{2 0 1 4} \\
\mathbf{\%}\end{array}$ & $\begin{array}{l}\mathbf{2 0 1 5} \\
\boldsymbol{\%}\end{array}$ \\
\hline 1 & Primary or basic & 31.9 & 20.7 & 17.8 \\
\hline 2 & Secondary & 34.4 & 29.9 & 32.9 \\
\hline 3 & Vocational education and training (VET) & 47.1 & 39.6 & 35.6 \\
\hline 4 & Higher education & 33.2 & 34.9 & 30.8 \\
\hline 5 & Total & $\mathbf{3 5 . 6}$ & $\mathbf{3 0 . 8}$ & $\mathbf{3 0 . 8}$ \\
\hline
\end{tabular}

Source: Geostat, 2015

Analysis has revealed (Torino 2016) different obstacles that young people face for entering the labor market, an important one is the inflation of qualifications in Georgia. Most times, job announcements require work experience, which first-time entrants to the labor market cannot have. Another severe impediment is a mismatch between demand and supply of skills. Despite the high unemployment, employers often find it challenging to locate the person with the skills in need. 


\section{Body of the Paper}

\subsection{The aim of the research}

The effect of youth unemployment is manifold: it harms a person's human and social capital and still hinders the development of the country.

Not much is known about the experience of unemployment in Georgia from the perspective of unemployed young people. Their knowledge, coping strategies and other related to youth issues are not well studied. Coping with the changes in social identity in unemployment has not been examined while having such evidence is essential for the development of youth employment support policy.

The study aims to get insights into the experiences, feelings, and thoughts of unemployed young people regarding their status, to examine the impact of their social identity on wellbeing. The study tries to answer the following research questions:

1. How is the status of unemployed perceived and what consequences youth associated with such a situation?

2. What link exists between social identification with the group of unemployed youth and well-being?

3. What strategies are used for escaping unemployment and how are they related to the perceived reasons for unemployment?

\subsection{Methodology}

Mixed method design, quantitative and qualitative was used.

A quantitative survey was conducted with 110 unemployed young people (???)

In-depth interviews were conducted with 24 participants (16 females and 8 males; aged from 21 to 29). The average duration of the meeting was 55 minutes.

For the survey, convenience and snow-balling sampling methods were used. A part of the participants were selected from the register of job-seekers (www.worknet.gov.ge); the selection, in this case, was based on ILO criteria, i.e. unemployed was considered to be one of 15 years of age or older, who did not to work (alike for one hour) before the interview for seven days, was looking for the job for at least four weeks and was ready to work in the next two weeks. To these criteria, one more was added, particularly having a qualification (of vocational or higher educational institution).

The survey research tool was a questionnaire covering the following issues:

- Background characteristics;

- Experience of unemployment,

- Attitudes towards unemployed,

- Social identity,

- Reasons for unemployment, 
- Self-esteem and life satisfaction,

- Copying with unemployment strategies.

Next, to be designed especially for the study questions, the questionnaire also contained some standard measures: The Rosenberg 10 item Self-Esteem Scale (1965) scored on a 4-point Likert type scale ranging from not at all (1) very much more than usual (4) (Shamir, 1986). Reliability of a Georgian version of scale is high $(\mathrm{a}=.76)$.

Life satisfaction was measured by the Satisfaction with the Life Scale (Campbell at al., 1976) with one statement added and was scored on a 7-point scale where one indicated strongly disagree, while seven strongly agree.

Social Identity measure was based on Weimeich's (1980) social identity instrument.12 relevant to the study constructs were selected and tested in a pilot semi-structured interviews. These were: dependent-independent; incompetent- competent; passive-active; angry-calm; poorrich; frustrated-satisfied; worthless-valuable; unsuccessful- successful; isolated from others connected with others; unhappy-happy; non-popular - popular; hopeless- hopeful ( $a=.719)$.

In-depth interviews were conducted using an interview guide, which covered attitudes and perceptions of unemployed youth and they're coping with unemployment identity strategies. All interviews were audio-taped and transcribed. The confidentiality was guaranteed.

\subsection{Results}

Data of both qualitative and quantitative studies are presented jointly. Quantitative data were analysed by SPSS 23. Qualitative data were subjected to content analysis.

Background data The survey was carried out with 110 respondents $(83.6 \%$ females and 16.4\% males). The average age was 22.4 years $(\mathrm{SD}=\mathbf{2 . 9}$, $\min =20$ years, $\max =29$ years). $86 \%$ of respondents were single, $12 \%$ married, $2 \%$ divorced. All respondents completed their first qualification (VET qualification, BA or MA) on average two years ago (SD=1.6, $\min =1$ year, $\max =9$ years).

In-depth interviews were conducted with 24 participants) 16 females and eight males, in the age range of 21-29 $(\mathrm{M}=23 ; \mathrm{SD}=2)$;

\section{Experience of unemployment}

Results show that $35 \%$ of the respondents have never been employed, $32 \%$ have been unemployed during 6-12 month; $18 \%$ of respondents experienced long-term unemployment, lasting at least one year, and $15 \%$ were unemployed for less than six months.

Most surveyed respondents $(64.5 \%)$ believe that their unemployment significantly affects their daily life.

Table 1 shows the leading effects of unemployment are financial problems, self-esteem, and a decrease of possibility to engage in social and cultural life. 
Table 1. Challenges related to unemployment (count of agree and strongly agree to Q16 1-5 scale)

\begin{tabular}{|l|l|l|}
\hline $\mathbf{N}$ & Items & $\begin{array}{l}\mathbf{\%} \\
\text { No 110 }\end{array}$ \\
\hline 1 & Financial Problems & 85.5 \\
\hline 2 & I am concerned about my sense of dysfunction & 70.9 \\
\hline 3 & Lack of participation in social/cultural life (theatre, cinema and etc. $)$ & 45.5 \\
\hline 4 & Lack of contacts with friends & 20.9 \\
\hline 5 & Problems of relationships with the family members & 20.9 \\
\hline 6 & Health's problems & 17.3 \\
\hline 7 & Exclusion & 12.7 \\
\hline 8 & Lack of initiatives from others to contact me & 9.1 \\
\hline
\end{tabular}

Respondents touched the above-listed problems also in the interviews. They

pointed out that unemployment limited their financial independence and decision-making power. They felt embarrassment, shame, and stress when forced to request money from their parents.

"I am 27! How can I feel OK when I have to ask my parents or my elder sister money? Who earns money in Georgia without working too hard? My parents have a low salary and spend the whole day at work! When I ask them for money, I feel sorry; it is terrible! I am at the age when I should support the family and not they - me (27 years old male)"

Unemployment has a negative influence on social relationships, limiting the circle of acquaintances and contacts with friends.

"When you are employed, you have more relations, go out often, are more optimistic, positive and active; can earn money and spend it as you wish (24-year-old female)".

"When I had a job, I spent more time with friends; Cannot say I lost my friends, but financial problems have a negative impact; I can get enough money from parents but the problem is that money is not mine, and I cannot spend it comfortably; it is excruciating.(25-year-old male)".

Having to acknowledge that one is still unemployed is associated with the feeling of inferiority that often prompts one to avoid meeting with the people as they usually ask them if they are still unemployed. These most often are neighbours and relatives:

"I feel discomfort to meet someone asks " Have not you find a job yet? Still unemployed? Poor kid". (28 years old male).

The adverse effect of unemployment is multifaceted and severe. It causes a feeling of despair and helplessness, results in low self-esteem and shame. 
"I feel disappointment, anger. Sometimes I ask myself -can I do anything at all?"(25 years old male).

"I am an educated person and have a good background, but have a feeling that nobody needs me. I am useless and worthless," (26-year-old female).

"I have a feeling that I am involved in a permanent struggle; I need a job, and I am doing my best, but there seems to be an invisible wall between me and society." ( 28 years old male).

\section{Social identity}

As pointed above respondents were asked to evaluate themselves, unemployed and employed youth on a 7-point scale on a 12 bipolar scale. The results are presented in Table 3.

Table 3. Evaluation of self, unemployed and employed youth 


\begin{tabular}{|c|c|c|c|c|c|c|c|}
\hline \multirow[t]{2}{*}{ \# } & \multirow[t]{2}{*}{ Characteristics } & \multicolumn{3}{|c|}{ Mean } & \multicolumn{3}{|l|}{ T criteria } \\
\hline & & Self & $\begin{array}{l}\text { Unemployed } \\
\text { youth }\end{array}$ & $\begin{array}{l}\text { Employed } \\
\text { youth }\end{array}$ & $\begin{array}{l}\text { self } \quad \& \text { } \\
\text { unemployed) }\end{array}$ & $\begin{array}{l}\text { self } \quad \& \\
\text { unemployed) }\end{array}$ & $\begin{array}{l}\text { unemplo } \\
\text { yed \& } \\
\text { employe } \\
\text { d }\end{array}$ \\
\hline & $\begin{array}{l}\text { Dependent- } \\
\text { independent }\end{array}$ & 3.32 & 3.30 & 3.68 & 1.479 & $3.173^{*}$ & $3.127 *$ \\
\hline & $\begin{array}{l}\text { Incompetent- } \\
\text { competent }\end{array}$ & 3.63 & 3.49 & 3.82 & $2.227^{*}$ & -1.813 & $3.165^{*}$ \\
\hline & Passive-active & 3.91 & 3.81 & 4.09 & $2.152 *$ & $1.962^{*}$ & $2.768^{*}$ \\
\hline & Angry -calm & 3.55 & 3.43 & 3.76 & 1.050 & $1.962 *$ & $4.054^{*}$ \\
\hline & Poor-rich & 2.66 & 2.68 & 3.15 & -.533 & $3.628^{*}$ & $4.263^{*}$ \\
\hline & $\begin{array}{l}\text { Frustrated- } \\
\text { satisfied }\end{array}$ & 3.18 & 3.23 & 4.20 & -1.913 & $-8.502 *$ & $9.164 *$ \\
\hline & $\begin{array}{l}\text { Worthless } \quad- \\
\text { valuable }\end{array}$ & 3.44 & 3.40 & 4.25 & -.815 & $-7.355^{*}$ & $12.366^{*}$ \\
\hline & $\begin{array}{l}\text { Unsuccessful- } \\
\text { successful }\end{array}$ & 2.90 & 2.88 & 3.45 & .044 & $5.978^{*}$ & $7.433^{*}$ \\
\hline & $\begin{array}{l}\text { Isolated from } \\
\text { others- } \\
\text { connected with } \\
\text { others }\end{array}$ & 2.20 & 2.10 & 2.47 & $2.588^{*}$ & $-2.082 *$ & $2.805^{*}$ \\
\hline & Unhappy-happy & 3.37 & 3.37 & 3.41 & .000 & -.391 & -.380 \\
\hline & $\begin{array}{l}\text { Non-popular }- \\
\text { popular }\end{array}$ & 2.56 & 2.18 & 3.15 & $3.348 *$ & $-5.204 *$ & $9.767 *$ \\
\hline & $\begin{array}{l}\text { Hopeless- } \\
\text { hopeful }\end{array}$ & 3.61 & 3.53 & 3.71 & $2.096 *$ & -1.181 & $2.221^{*}$ \\
\hline & $\begin{array}{lr}\text { Average } & \text { score } \\
\text { for } & \text { all } \\
\text { dimensions } & \end{array}$ & 3.19 & 3.14 & 3.57 & & & \\
\hline
\end{tabular}

$* \mathrm{P}<0.01$

Across all the items of the scale employed youth is evaluated most favourably, followed by the self, with unemployed youth assessed the least favorable.

The analysis shows that unemployed youth identified themselves with an unemployed group of youth. The difference between evaluation of employed and unemployed (one sample T-test, $\mathrm{M}=.043, \mathrm{SD}=0.52, \mathrm{p}<001)$, as well as the difference between working and self $(0.37 ; \mathrm{SD}=.47$; $\mathrm{p}<.001)$ is statistically significant. 


\section{Reasons for unemployment}

Listed in Table 2 the reasons for unemployment clearly show that unemployment is most often attributed to the educational results-lack of knowledge and skills, followed by lack of demand of a given qualification and then to nepotism or economic situation in the country. Least of all unemployment is associated with respondents own passivity.

Table 2. Reasons for unemployment

\begin{tabular}{|l|l|l|}
\hline & Items & $\begin{array}{l}\text { \% } \\
\text { No 110 }\end{array}$ \\
\hline 1 & Lack of professionalism- lack of knowledge and skills & 87.3 \\
\hline 2 & Lack of demand for my qualification on LM & 81.8 \\
\hline 3 & $\begin{array}{l}\text { Employers tendency to employ relatives and people they } \\
\text { know }\end{array}$ & 79.1 \\
\hline 4 & Lack of jobs in the country & 75.5 \\
\hline 5 & Passivity in searching for the job & 33.6 \\
\hline
\end{tabular}

Nepotism often named external cause is also frequently mentioned in interviews.

"We all know that nepotism always was, is and will be in Georgia! It is a Soviet legacy! But I cannot understand why I should employ my relative who is not professional? What he or she can do " (27 years old female)

"I think my unemployment is due to the lack of jobs in the country and the fact that nepotism is widely spread in Georgia. Sometimes vacancies are false; employers even do not listen to us during interviews (24-year-old male)".

Besides nepotism respondents also mentioned other external reasons for their unemployment, one of them being the strategy of saving money by the organization :

"Sometimes organizations need new cadres but do not recruit a candidate to save money. They prefer to have interns, whom they do not pay (22-year-old female)."

As for reasons of unemployment associated with the person the lack of work experience was often mentioned, and a low level of practical skills:

"Jobs require experienced candidates; it is almost impossible to have such an experience at my age. If no one gives me a chance to start work how can I have the relevant experience??. (26 years old female)".

"I think there are problems in the education system. Universities are more focused on providing theoretical knowledge and much lesson practical skills. That's why young people do not meet the requirements of employers, and a big gap is created: unemployed people have theoretical knowledge while employers need cadres with practical skills. "(28 years old male) 


\section{Attitudes towards unemployed}

Most respondents (81.8\%) say, family, mostly parents provide a lot of support to them: "Family is not a problem. My family does not force me to take any job. I also think that it is better to work by my profession, but I felt uncomfortable to ask my family money; it makes me feel bad" (25-year female).

While family provides material help, friends provide unemployed youth with social support. As for the social attitude to the unemployed youth can be different. It depends on the attribution of the reason for unemployment. The reaction is positive when it is attributed to the scarcity of jobs in the country and is harmful when it is assigned to the passivity or low qualification of unemployed.

"If the public believes he/she is a "good type of person", he/she tries but cannot find a job, the attitude towards him/her is not negative, but if he is not perceived as having this quality and he is not seeking employment, society expresses a more negative attitude " (24yearsold male). Survey respondents see the gender difference in attitudes towards unemployed. $72 \%$ of respondents in a qualitative interview think the attitude towards unemployed men is more positive than to unemployed women.

The attitude of employers towards unemployed is more harmful. Employers invariably express doubt on candidates abilities when they learn that they have been unemployed for a long time. The question as for why they are unemployed is almost always asked.

"Whatever you say it's obvious they do not believe. Employers have their understanding and firm attitude that if you are unemployed, it is your fault" (27 -year-old female).

In conclusion, it can be said unemployment has a negative connotation and unemployed youth identify themselves with an unemployed group of youth. They describe their condition in negative terms pointing to a feeling of despair, dependence and social isolation. So both the survey results and in-depth interviews revealed mostly negative experiences associated with unemployment: financial dependence on a family, a feeling of helplessness, the expertise of deficiency of needed skills, negative attitude of society and especially of employers. Critical opinion of unemployed youth towards the education system was evident because of providing low qualification and offering degrees for professions not needed in LM.

The adverse effect of unemployment of personality was buffed by the attribution of unemployment to external rather than internal causes... Respondents showed having reserved for optimism mostly based on the financial support of family and social support of friends.

\section{Copying with unemployment strategies}

Majority of respondents are seeking individual copying strategy to unemployment, actively trying personal mobility, changing the status of unemployed. $47 \%$ of respondents often and $34 \%$ from time to time are looking for jobs, while $19 \%$ stopped trying.

Most widespread activity for job seeking is sending CVs, $56.4 \%$ in the table is $47.3 \%$ pointed as being often engaged in it. 
Table 5. Job searching strategies

\begin{tabular}{|c|c|c|}
\hline & Items & $\begin{array}{c}\text { \% } \\
\text { Often } \\
\text { No 110 }\end{array}$ \\
\hline 1 & Send CVs & 47.3 \\
\hline 2 & Attend training sessions & 21.8 \\
\hline 3 & $\begin{array}{c}\text { Ask my relatives and acquaintances to help in } \\
\text { employment }\end{array}$ & 13.6 \\
\hline 4 & Attend "job-fairs" and try to meet potential \\
& employers & 6.4 \\
\hline
\end{tabular}

As is clear from Table 5 one fifth of the respondents (21.8\%) attends training/seminars/workshops to improve their skills and knowledge. Those who do so point that if not helping find a job, this activity at them feel better and useful.

"I intensively attend various workshops or seminars. I can say I am a "permanent student." So far it helps me; I do not think I am worthless"'(26- year-old male).

In the interviews, respondents pointed at other activities that assist them in mitigating the adverse effect of unemployment, among these activities, is pursuing hobbies or doing internships.

Length of unemployment does not affect the absolute amount of difference between selfunemployed or self-employed.

Respondents were presented with the list of 4 activities targeting job seeking. They were requested to point out how often they used each of them. So they could mark from one to 4 actions.

Length of unemployment was associated with job search activity, i.e., several jobs-seeking methods used. ANOVA showed the difference between short, long and never employed (F $7.01, \mathrm{df}=2, \mathrm{p}<.001)$. The most active were unemployed for an extended period ( $\mathrm{M} \mathrm{1.111,} \mathrm{Sd}$ $.96)$ Then those who have never been employed $(\mathrm{M}=.95, \mathrm{SD}=.74)$ and least active were those who were unemployed for a short period $(\mathrm{M}=.53, \mathrm{SD}=.50)$. Trainings also were most of the attended by those who did not work for an extended period $(\mathrm{M}=.55, \mathrm{SD}=.51)$ than those who did not work for a short period $(\mathrm{M}=.23, \mathrm{SD}=.43)$ and least by those who has never worked $(\mathrm{M}=.05, \mathrm{SD}=.22)(\mathrm{F}=10.0 ; \mathrm{df}=2 ; \mathrm{p}<.001)$.

Besides the length of unemployment job seeking activity was linked with the perception that one's qualification is not needed in $\operatorname{LM}(\mathrm{F}=3.74$; $\mathrm{SD} d=2 ; \mathrm{p}<.05)$. More people who thought so were active job seekers $(\mathrm{M}=1.25 ; \mathrm{SD}=.97)$ compared to those who did not believe so $(\mathrm{M}=0.78 \mathrm{SD}=.84)$ Job seeking activity also was linked with the perception of own low 
qualification $(\mathrm{F}=7.4 \mathrm{~d}=\mathrm{p}<001)$ those who thought so were less active $(\mathrm{M}=0.43 ; \mathrm{SD}=.51)$ compared to those who did not believe so $(\mathrm{M}=.94 \mathrm{SD}=.94)$

Perceived reasons for unemployment was not linked with job search activity but was connected with training. Those who thought the reason of unemployment was low demand of their qualification were more involved in training $(\mathrm{F}=4.24 ; \mathrm{d}=\mathrm{p}<.05, \mathrm{M}=.40 \mathrm{SD}<.50)$, than those who did not think so $(\mathrm{M}=.18, \mathrm{SD}=.39)$. It is surprising that persons among those who perceived that did not have sufficient qualification attended workshops $(F=4.4, f d=p<.05, M=00$, ) than those who did not say this $(\mathrm{M}=.26, \mathrm{SD}=.44)$. So attendance of workshops was linked somewhat with the change of the profession than mastering own qualification.

\section{Unemployment and well being}

Mean score of optimism of respondents is $13.78(\mathrm{SD}=2.46)$.

Self -esteem is 29.13 ( $\mathrm{SD}=3.17)$, which is lower than the norm in Georgia (29.54)

$35.5 \%$ is satisfied, $49.1 \%$ neither satisfied nor dissatisfied, $15.5 \%$ unsatisfied with life. This is lower than the norm in Georgia where $82 \%$ is met, $11.3 \%$ is neither satisfied nor unsatisfied, and $6.7 \%$ is dissatisfied.

Optimism was correlated with satisfaction with life $(\mathrm{r}=.387, \mathrm{p}<.001)$ and self-esteem $(\mathrm{r}=461, \mathrm{p}<.001)$.

As table 7 shows people who seek a job intensively are more satisfied with their lives and have higher self-esteem;

Table 7. Job search, identity with unemployed groups, self-esteem, life satisfaction

\begin{tabular}{llllll}
\hline & Job Search & M & SD & F & Sig \\
\hline Self-esteem & Intensively & 27.37 & 3.94 & 60.516 & .000 \\
& From time to time & 24.82 & 2.89 & & \\
& Stopped searching & 25.0 & 3.83 & & \\
Life satisfaction & Intensively & 4.50 & 1.99 & 4.912 & .009 \\
& From time to time & 4.38 & 1.82 & & \\
& Stopped searching & 3.67 & 2.73 & & \\
& & & & & \\
Identity with unemployed & Intensively & 3.06 & .28 & \multirow{2}{*}{1.163} & \multirow{2}{*}{.316} \\
& From time to time & 2.95 & .24 & & \\
& Stopped searching & 3.05 & .52 & & \\
\hline
\end{tabular}

The highest self-esteem has people who attend courses/training $(M=28.75 ; S D=4.83$ 


\section{Discussion and Conclusion}

The research provides a reasonable basis for understanding how young unemployed people feel, think and perceive their unemployment and how they try to deal with the negative social status of unemployed.

\section{Experience of unemployment}

Results of the study show that unemployment affects many dimensions of the life of youth among which economic and social aspects are the most salient. Unemployment diminishes financial independence and restricts social activities.

Our results fit well with predictions of deprivation theories (Ervasti and Venetoklis, 2010). According to the financial problems are not the only source of distress for unemployed people as psychosocial consequences have a severe impact as well (Nordenmark 1999b; Nordenmark and Strandh 1999). Winkelmann and Winkelmann (1998) believe that "non-pecuniary cost of unemployment," is even more important than the monetary cost of unemployment. Other researchers also confirm this approach (Clark and Oswald 1994; Fergusson, John Horwood and Woodward 2001; Hammer 2000).

Results are also by findings of Jahoda et al. (1933)that show a reduction in social contacts, a lack of participation in social life, the absence of an acceptable status, and the lack of regular activities among unemployed youth.

The effect of unemployment in youth is especially harmful as an obstacle to the process of identity formation which may not be completed.

Although our respondents perceived unemployment as stigmatising, they still point to the positive attitude of society to them.

This finding agrees well with the notion of the impact of economic context on attitudes toward unemployed (Kelvin and Jarrett, 1985). The effect of the stigma of unemployment is higher during low unemployment and lower in times of high unemployment (Omori, 1997). High level of unemployment in Georgia among young people and economic crisis seem to frame a more patient evaluation of society of unemployed youth.

\section{Social identification and well being}

Research showed that identification with unemployed is not related to low self-esteem and in a lesser degree to life satisfaction. This finding contradicts with SIT, which proposes that it is difficult to derive a positive self from a membership of a lower status group (Tajfel, 1978), especially for groups which low social standing is perceived to be legitimate, such as the unemployed (Breakwell, 1986).

The research shows that life satisfaction is correlated to identification with employed youth, but not positive self-esteem. It means that while life satisfaction is related to the identification of working youth group high self-esteem is not. The source of positive self -esteem is not strongly linked with the dimension "employment-unemployment," but as our research shows 
helping families, attending trainings /seminars or having hobby helps the unemployed youth to form the "alternative identity" and maintain positive self-esteem.

Strategies to deal with identity loss of unemployment

Research shows that unemployed youth predominantly use individual mobility strategy to escape membership of the stigmatised group. The searching job is most frequently used mean for achieving this. Our research shows that attempts in finding a job are associated with higher while stopping to do this with lower self-esteem and life satisfaction.

Next to mobility social reconstruction is considered an effective strategy for dealing with stigma. According to it finding a job is perceived beyond one's control and depend on the external circumstances, such as lack of employment and prejudice and discrimination of employers. (Crocker \& Major, 1989).

Kingdon and Knight (2002) point at three primary reasons there might be a lack of active job searching among persons who want to work:1. The high local unemployment rate or the long duration of one's unemployment; 2.recruitment methods of employers; and 3.the cost of job searching Our research shows that a significant proportion of participants (over 75\%) attribute their unemployment to external factors beyond their control, such as high local unemployment and biased recruitment methods of employers.

Participants use disengagement coping (Compas et al., 2001; Miller \& Kaiser, 2001) concretely psychologically disconnect their self-esteem from the evaluation of unemployed youth.

Actively looking and applying for jobs finding no, negatively affects the well-being of the unemployed (Miltenburg \& Woldringh, 1989). This fits the hypothesis of learned helplessness (Seligman, 1975). The reduction of job-seeking behaviour can be understood as a coping strategy. By not applying for jobs, the unemployed avoid adverse outcomes and feelings, such as constant failure and rejection by employers.

Thus, to sum up, unemployment is a negative experience for young people. They try to deal with identity

Conclusions

- Experience of unemployment is negative. It causes financial problems, nurtures a feeling of dependence, is linked to reduced opportunities for social and cultural involvement, decreases interactions with friends and relationships.

- Both short and long unemployed youth identify themselves with the unemployed group.

- Unemployment is mostly attributed to the failure of the educational system, providing teaching in qualifications not needed in LM or low level of education, especially of practical skills.

- The attitude of society towards unemployed differs according to what is unemployment is attributed to, it is more positive when it is assigned to the economic situation in the country and hence to lack of jobs, but is more harmful when attributed to the person's lack of job-seeking activity or her qualification. 
- To escape the social identity of unemployed youth is trying social mobility. They are engaged in job-seeking activities, mostly by sending CVs and seeking help in their own social surrounding in finding the job. The long-term unemployed are more active than the short-term unemployed. The perceived reasons for unemployment do not affect jobseeking activities but affect the attendance of workshops. Those who attribute unemployment mostly to lack of demand on LM of their qualification attend seminars most probably for gaining new, more demanded in LM qualification.

- Unemployment effects well-being. Unemployed youth is less than the general population satisfied with life although they have a similar level of self-esteem. One reason for this may be the hopefulness associated with a young age of respondents and still, even in case of extended unemployment, not a very long period since graduation and financial and social support they receive from their families and friends.

\section{References}

De Witte, H., \&Hooge, J. (1997). Adaptation to unemployment? A cross-sectionalcomparison of short-term and long-term unemployed. GedragenGezondheid, 25(3), 145-155.

Kingdon, G. G., \& Knight J. (2002). Unemployment in South Africa: The nature of the beast. World Development, 32,391-408.

Kingdon, G. G., \& Knight, J. (2006). The measurement of unemployment when unemployment is high. Labour Economics, 13, 291-315.

Kokko, K., Pulkkinen, L. \&Puustinen, M. (2000). Selection into long-term unemployment and its psychological consequences. International Journal of Behavioral Development, 24(3), 310320.

Jahoda, M. (1982), Employment and unemployment. A social psychological analysis. Cambridge: Cambridge university press.

Lorenzini J., G Giugni, M. (2012), “Employment Status, Social Capital, and Political Participation: A

Comparison of Unemployed and Employed Youth in Geneva", Swiss Political Science review, 18(3): 332-351.

Waters, E., \& Moore, K. A. (2001). Reducing latent deprivation during unemployment: The role of meaningful leisure activity. Melbourne: University of Melbourne.

Blau, D.M. and P.K. Robins (1990): Job Search Outcomes for the Employed and Unemployed, Journal of Political Economy 98, pp. 637 - 655. 
Creed, P.A. \&Macintyre, S.R. (2001). The relative effects of deprivation of the latent and manifest benefits of employment on the wellbeing of unemployed people. School of Applied Psychology, Griffith University.

De Witte, h., Hooge, J., \&Vanbelle, E. (2010). Do the long-term unemployed adapt to unemployment? Romanian Journal of Applied Psychology Vol.12, No.1, 8-14

Erikson, E. H. (1959). Identity and the life cycle; Selected papers, with a historical introducti on by David Rapaport. New York: International University Press.

Kapuvári, V. (2011). Psychological effects of economic recession and unemployment. European Journal of Mental Health, 6, 83-93

Sheeran, P, Abrams, D. \& Orbell, S. (1995). Unemployment, Self-Esteem, and Depression: A Social ComparisonTheory Approach. Basic and Applied Social Psychology, 17(1\& 2), 65-82.

Vansteenkiste, M., Lens, W., De Witte, S.D., De Witte, H. \&Deci, L.E. (2004). The "why" and "why not' of job search behaviour: Their relation to searching, unemployment experience, and well-being. European Journal of Social Psyxhology, 34, 345-363.

Vansteenkiste, M., Lens, W. De Witee, H. \& Feather, N.T. (2005). Understanding unemployed people's job search behaviour, unemployment experience and wellbeing: A comparison of expectancy-value theoryand self-determination theory. British Journal of Social Psychology, 44, 269-287.

Sheeran, P., \&McCarthy, E. (1990). The impact of unemployment upon self-conception: Evaluation, affection, consistency and involvement dimensions. Social Behavior, 5, 351-359.

Sheeran, P., \&McCarthy, E. (1992). Social structure, self-conception and well-being: An examination of four models with unemployed people. Journal of Applied Social Psychology, 22, 117-133.

Tajfel, H. (1974). Intergroup behavior, social comparison and social change. Unpublished Katz-Newcomb lectures presented at the University of Michigan, Ann Arbor.

Tajfel, H. (Ed.). (1982). Social identity and integroup relations. Cambridge, England: Cambridge University Press. Tajfel, H., \&Turner, J. C. (1979). An integrative theory of intergroup conflict. In W. G.

Austin \&S. Worchel (Eds.), The social psychology of intergroup relations (pp. 33-47). Monterey, CA: Brooks/Cole. 
Winefield, A. H., \&Tiggeman, M. (1985). Psychological effects of unemployment: Effects, predisposing factors and sex differences. Journal of Occupational Psychology,58,229-242.

Outten, H. R., Schmitt, M. T., Garcia, D. M., \&Branscombe, N. R. (2009). Coping options: Missing links between minority group identification and psychological well-being. Applied Psychology: An International Review, 58, 146-170

Schmitt M. T., Spears R., Branscombe N. R. (2003). Constructing a minority group identity out of shared rejection: The case of international students. European Journal of Social Psychology, 33, 1-12.

Iyer A., Jetten J., Tsivrikos D., Postmes T., Haslam S. A. (2009). The more (and the more compatible) the merrier: Multiple group memberships and identity compatibility as predictors of adjustment after life transitions. British Journal of Social Psychology, 48, 707-733.

Latrofa M, Vaes J, Pastore M, \&Cadinu M (2009). United we stand, divided we fall! The protective function of self-stereotyping for stigmatised members' psychological well-being. Applied Psychology: An International Review, 58, 84-104.

Tajfel, H., \& Turner, J.C. (1979). An integrative theory of intergroup conflict. In W.G. Austin \& S. Worchel (Eds.), The social psychology of intergroup relations (pp. 33-47). Monterey, CA: Brooks/Cole.

Turner, J.C. (1982). Towards a cognitive redefinition of the social group. In H. Tajfel (Ed.), Social identity and intergroup relations (pp. 15-40). Cambridge: Cambridge University Press.

Turner, J.C., Hogg, M.A., Oakes, P.J., Reicher, S.D., \&Wetherell, M.S. (1987). Rediscovering the social group: A self-categorization theory. Oxford: Blackwell.

Winkelmann, L.; Winkelmann, R. (1998). Why are the Unemployed so Unhappy? Evidence from Panel Data. Economica, Vol. 65, 1 - 15

Waters, L., \& Moore, K. (2001). Coping with economic deprivation during unemployment. Journal of Economic Psychology, 22(4), 461-482

Vinokur, A., and Caplan, R. (1987). Attitudes and social support: Determinants of job-seeking behaviour and well-being among the unemployed.Journal of Applied Social Psychology, 17, 1007-1024

Beck, Ward, Mendelson, Mock, \&Erbaugh, 1961.

Blanz et al., 1998; 
Bolton \&Oatley, 1987; Whyte, 1956), (Atkinson, Liem., \&Liem, 1986).

Branscombe, Schmitt, \& Harvey, 1999;

Callero, 1992, 1994; Turner, 1978;

Catalano, 1991; Kessler, Turner \& House, 1988; 1989

Catalano, 1991; Nordenmark , 1999a; Johada et al. 1933; Pal 2006).Paugam 2004;

Crocker \& Major, 1989; Crocker et al., 1998

Diener\&Diener, 1996,

Ellemers, Spears, \&Doosje, 1997;

Erikson (1959;

Friedland, D.S., \&Vinokur, A.D. 1998).

Friedli, 2009.

Jackson \&Warr, 1984;

Kessler \&Mummendey, 2002;

Maslow, 1954;

Miller \& Kaiser, 2001;

Miller \& Major, 2000

Mummendey, Kessler, Klink, \&Mielke, 1999

Rosenberg, 1965,

S. A. Haslam, 2004; Schmitt \&Branscombe, 2002;

Schmitt et al., 2014;

Tajfel, 1978;

Young, 2012;

Geostat

Torino 